Abbott Malcolm (Orcid ID: 0000-0002-6735-6074)

\title{
WAS IT POSSIBLE TO STABILISE THE PRICE OF WOOL? ORGANISED WOOL MARKETING 1916 to 1970
}

\author{
Malcolm Abbott \\ Corresponding author \\ mabbott@swin.edu.au \\ Swinburne \\ Melba Ave \\ Lilydale \\ Australia \\ 3140 \\ David Merrett \\ dtm@unimelb.edu.au \\ university of Melbourne \\ Management and Marketing \\ level 10, The Spot \\ 198 Berkeley Street \\ Carlton \\ Melbourne \\ Victoria \\ Australia \\ 3010

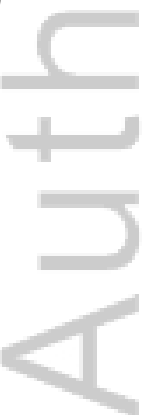

This is the author manuscript accepted for publication and has undergone full peer review but has not been through the copyediting, typesetting, pagination and proofreading process, which may lead to differences between this version and the Version of Record. Please cite this article as doi: 10.1111/aehr.12136

This article is protected by copyright. All rights reserved. 
WAS IT POSSIBLE TO STABILISE THE PRICE OF WOOL? ORGANISED WOOL

MARKETING 1916 to 1970

\begin{abstract}
Wool is the only Australian commodity for which there has been an attempt to organise price stability through a buffer stock scheme (1970-91). Growers pressed for the introduction of a scheme since the early 1920s. We test the veracity of claims that the sale of the stockpiles optimised growers' returns. We also simulate the likely outcomes of the Reserve Price Schemes (RPS) proposed in 1925 and 1952, respectively. Our findings are that post-war stockpile disposals did not optimise woolgrowers' incomes, the undercapitalised proposed RPS of the 1920s would have collapsed in the depression and that the post-1952 RPS would have been in considerable difficulty.
\end{abstract}

JEL Categories: Q11, Q18, N47, N57

Keywords: wool, reserve price, buffer stock, Australia

This article is protected by copyright. All rights reserved. 
The prices received by many Australian farmers during the twentieth century have been raised by state sanctioned interventions; the most common being a 'home price support' scheme where growers received pooled revenues from domestic prices raised by taxes on imports and exports (Campbell 1980). Woolgrowers, in contrast, could not benefit from such an arrangement as nearly all wool was exported. The industry norm was that all the wool shorn within each season was sold at auction at whatever prices were necessary to clear stocks. Wartime experience, compulsory acquisition of wool by the British government, and administered release of wool from large stockpiles subsequently, showed that an alternative and, in the minds of many growers a superior, form of marketing was viable (Dyason 1928; Sims nd.). This idea led to political agitation by an increasing section of growers for the introduction of a reserve price scheme (RPS) from the early 1920s, until its eventual introduction in 1970 (Merrett and Ville 2016). Ostensibly, the proposed schemes were supposed to be designed to stabilise prices and to reduce price fluctuations, although some growers and associated groups wanted to use the schemes to attempt to raise world prices for wool.

Most of the literature about the imperial politics of the compulsory acquisitions, the administration of the appraisal system, the disposal of post-war surpluses and the arguments for and against RPSs uses an historical methodology. While authors disagreed, their arguments were seldom couched in economic analysis. Inter-war exceptions were the academic economists J. B. Brigden and L. G. Melville, and the South African wool marketing specialist, A. F. Du Plessis (Brigden 1932; Du Plessis 1931). ${ }^{1}$ One of the main contentions of the advocates of the organised marketing of wool was that the First World War and Second World War experiences of wool acquisition and subsequent disposal of stockpiles immediately after both wars, were successful at moderating price fluctuations, or even had the effect of raising grower incomes. A number of later writers also have argued that in light of this claimed success, an RPS scheme, had it operated, could have stabilised prices during the post-First World War and Second World War periods (Dyason 1928; Scott 1936; McCarthy 1967; Fyfe 1996; Tsokhas 1990; White 1982; Hitchins nd.; Sims nd.; Bailey 1966; Barnard 1987; Keneley 2001.

Despite these claims, rigorous quantitative evaluation of the impact on grower incomes of the two wartime stock disposal schemes has not been undertaken. Nor have the difficulties involved in operating an RPS in the two post-war periods been properly analysed. In this paper, therefore, we ask counterfactual questions in order to test these claims of those arguing in favour of a marketing authority to stabilise the price of wool. We do this by determining if:

- grower incomes were maximised by the disposal of wool from post-First World War and Second World War wool stockpiles;

- by determining the potential viability of an RPS in the 1920s and 1930s; and

- by determining the potential viability of an RPS in the 1960s.

In undertaking this task, we employ the methodologies used by Australian agricultural economists to evaluate the optimal strategies to dispose of the stockpile of the 1990s (Powell and Campbell 1962; Parish 1964; Gruen 1964; Lloyd 1965; Sturgess 1968; Hone and Hope 1994; Hertzler; 1994; Haszler et al. 1996).

The paper contributes to the broader literature by examining the difficulties involved in operating price stabilisation schemes in Australia. Historically, these questions are

\footnotetext{
${ }^{1}$ For Melville's views see: Turnell (1998).
} 
important because the disposal of the wartime wool stockpiles provided encouragement to agricultural interests, more generally, to lobby for organised marketing measures. Had more rigorous economic analysis and discussion taken place at the time it is possible this encouragement might not have been so strong. In addition, we show that the stock disposals were sub-optimal in terms of their impact on grower income and that there were inherent difficulties in operating an RPS at this time, and thus reinforce the contemporary view that price stabilisation schemes are inherently difficult to operate successfully.

The paper is structured as follows. In the first section we provide a background on the use of counterfactual studies in the wool industry. In addition, this section provides a brief outline of the wartime purchasing agencies and those that handled the disposal of the postwar stockpiles, the British Australian Wool Realisation Association, hereafter BAWRA, and the United Kingdom Wool Disposals Limited (the Joint Organization), hereafter JO, and its Australian subsidiary, the Australian Wool Realization Commission, hereafter AWRC. In section two, we calculate the optimal rate of disposal after both wars with the actual sales made by BAWRA and the JO in order to determine the impact of the disposals on grower income, and therefore the success of the schemes. In the third section, we model the likely form an RPS would have taken in the 1920s and 1930s. In section four, we do the same for the 1950s and 1960s, drawing on the experience of New Zealand and South Africa, both of which operated RPSs in this period. In doing so, we determine the level of difficulty and risk involved in conducting these proposed schemes. We offer a conclusion in the final section.

Australia has had a long history of organised agricultural marketing, dating back to the 1920s. The period of the 1920s and 1930s was one of considerable volatility in agricultural markets and price support of stabilisation schemes were introduced in several countries. At times since then some prominent economists supported market stabilisation programmes in the agricultural sector more broadly, mainly because it reduced levels of risk to farmers and therefore encouraged investment. ${ }^{2}$ In the Australian case, each of the states introduced agricultural marketing authorities in the 1920s. The first schemes in each state were: New South Wales - rice 1928; Victoria - dried fruits 1925; Queensland - wheat 1920; South Australia - dried fruits 1928; Western Australia - dairy 1922; Tasmania - meat 1924 (Standing Committee on Agriculture 1980). In addition, the federal government operated export schemes for butter, meat and dried fruits from 1925 and wheat from 1939.

After the Second World War, it became generally recognised in agricultural economics that stabilisation schemes faced three major practical problems that put them at risk. First, the long-run price level about which stabilisation takes place may change over time (because of changes in production costs or consumer tastes), requiring the updating of the stabilisation range and price floor. Estimating these changes or anticipating the changes can be difficult. Secondly, even if the stabilisation level is appropriately defined, the intervention authority may lack the resources to keep the price at that level, even if the price fluctuations are relatively mild. Thirdly, it is possible that a guaranteed minimum price might cause over-production and rising surpluses (Williams and Wright 1991). Commodity prices are volatile because of low price elasticities of demand and supply in the short-run, which means that supply and demand shocks can cause large changes in prices. These price shocks can create difficulties with updating price support ranges. These shocks became central to the problems faced by a number of stabilisation schemes in the 1970s and 1980s such as those internationally for tin, sugar, and cocoa (Gilbert 1996; Cashin et al. 1999; Salant 1983).

\footnotetext{
${ }^{2}$ These economists include Keynes (1942); Houthakker (1967); and Newbery and Stiglitz (1981).
} 
Counterfactual assessments of these schemes have been undertaken, but they tend to be forward looking. That is, they tend to look at different ways in which schemes can be operated into the future, rather than be a part of historical analysis of past schemes, both real and hypothetical (Gruen 1964; Campbell et al. 1980; Hone and Hope 1994; Hertzler 1994; Haszler, Chisholm, Edwards and Hone 1996). This is the first study that has attempted this approach to the proposed schemes of the 1920s, 1930s, and 1950s for the Australian wool industry.

During both wars, the British Government was anxious to secure access to key raw materials and foodstuffs, and it did so through a series of long-term contracts with members of the Empire. To that end, during the First World War the British and Australian governments entered into an agreement to purchase all of the wool produced. The contract was to operate from the 1916/17 wool season and for one year after the end of the war and it was agreed that the average price would be $15.5 \mathrm{~d} / \mathrm{lb}$, roughly 50 per cent above the pre-war levels. The actual price received was higher, $16.5 \mathrm{~d} / \mathrm{lb}$, because of a shift in the mix of wool produced. A similar agreement occurred later during the Second World War and under this agreement; the price received by the growers was $14.1875 \mathrm{~d} / \mathrm{lb}$ from 1939 and increased to 15.453125d/lb in May 1942. ${ }^{3}$ Similar purchasing schemes were introduced during both wars with other Dominions (New Zealand and South Africa) and the Falkland Islands. ${ }^{4}$ In Australia a statutory authority, the Central Wool Committee, appraised the wool clip during the operation of the contracts as the auction system had been suspended during both wars (Fyfe 1996; Scott 1936).

Following the end of the purchase agreements, new agencies, BAWRA and JO, were created to dispose of the accumulated stocks of wool owned by the British Government. The stockpiled wool was sold via auction, together with the new wool produced by the annual shearing of the national flock. The growers stood to gain from the disposal of wool for which they had already been paid, as they received 50 per cent of any excess over the contract price, the other half going to the British Government. As shown in Table 1 the outstanding stocks at the end of the 1919/20 season were 2.692 million bales of which 1.863 million was Australian wool. This stock was about half of the total production of the five main exporting countries over the period 1909/10 and 1913/14, and about three-quarters of the pre-war global production of merino wool. ${ }^{5}$ The stock of wool owned by the British Government at 31 July 1945 was transferred to the JO and included 10.4 million bales of wool, 6.8 million bales of which was Australian (Table 2). The stocks held by JO and other governments at the end of the Second World War were the equivalent of world production.

The stockpiles were sold off over three and a half and six years respectively, much faster than BAWRA and JO management believed was possible. For instance, Sir John Higgins, chairman of both the Central Wool Commission and BAWRA, informed the wool selling brokers that: 'the carryover would probably take 5,6 or even 7 years to realise, but that was a much better scheme than forcing it on the market now. ${ }^{6}$ After the Second World

\footnotetext{
${ }^{3}$ Australia, Commonwealth Bureau of Census and Statistics, Official Year Book, vol. 36 (1944-45), p. 1106; McCarthy (1967); White 1982). The 1936-39 average was exceeded by 21/2 per cent from 1939 to 1942 and by 171/2 per cent between 1942 and 1946.

${ }^{4}$ Britain and these three exporting nations produced around 60 per cent of the world's apparel wool. A large market in wool operated during the First World War comprising the Latin American exporters, the United States, and continental Europe with prices well above the long-term contract values. Blau (1946).

${ }^{5}$ Blau (1946) Tables III and IV, p. 184. Blau's data are of millions of lbs greasy. We have converted her figures to bales using a conversion rate of 320 pounds to the bale.

${ }^{6}$ National Council of Wool Selling Brokers, Minutes of Executive Committee of National Council of Wool Selling Brokers of Australia, 17 August 1921, Volume 1920-23, p. 273.
} 
War, it was the view of the delegates from Britain and the three Dominion countries meeting at London in April and May of 1945 that: '...the period required to dispose of the accumulated stocks would be about 13 years from June $30^{\text {th }} 1945^{\prime}$ (McCarthy 1967). There was a marked tension at the heart of the disposal of wartime stocks as the interests of Britain and the wool growing nations diverged. Britain wanted access to wool during the conflict, but its textile industry wanted to pay as low a price as possible in peacetime. The growers on the other hand wanted to receive the highest possible price. Therefore, the British pushed for a faster sell-off of the stockpile than the growing countries after both wars.

The disposal of the wartime stocks made a considerable profit, Australian growers received £30.2 million from BAWRA and £62.3 million from the JO (Dyason 1928; McCarthy 1967). This raised expectations that the continued operation of a central marketing authority, a combination of Central Wool Commission, BAWRA and the AWRC, could raise the price of Australian wool. The marketing of wool during and after both wars had developed expertise in centralised acquisition, valuation via appraisal and, more importantly, knowledge about how much wool be held back from the market to lift prices (Fyfe 1996). The Australian Government, however, did not possess either the financial means or the political support to compulsorily purchase Australian wool in peacetime and so a post-war RPS would have to be financed by other means. Higgins himself in 1922 advocated that BAWRA's shareholders commit their £16 million worth of undistributed profits as capital to fund such a scheme (Higgins 1922). In 1925, he proposed that the capital of such a scheme should be increased to $£ 50$ million to be raised initially by a government loan that would eventually be offset by a levy on growers of five per cent of the sale price of their wool (Higgins 1925). After the Second World War growers in the producer countries paid a contributory charge towards the operation of the JO. Between 1946/47 and 1949/50, Australian growers paid $£ 42.1$ million and there were further levies imposed on growers to fund the acquisition of wool that failed to meet the reserve prices set during the sale of stocks held by the JO and AWRC (McCarthy 1967). The proposal to continue the JO after 1951 would have provided a capital of $£ 59$ million for Australia's involvement in the four-country scheme, to be funded by a grower levy of $7 \frac{1}{2}$ per cent with any shortfall to be made good by a government loan.

Australian growers voted against the proposals to introduce an RPS in 1922 and again in 1951. On both occasions, conservative graziers, wool-selling brokers, and the powerful pastoral houses that were opposed to government intervention on the grounds of ideology and self-interest campaigned for rejection. In contrast smaller growers were more favourably disposed towards the use of an RPS to offset price falls, however, they voted to take the undistributed profits held by BAWRA and the contributory charges held by AWRC in cash rather than invest them as capital for an RPS.

Britain had no interest in extending the operations of BAWRA, however, its attitude changed after the Second World War when it agreed, after a series of conferences, to participate in an Australian proposal to extend the operations of the JO along with New Zealand and South Africa (Australian Wool Realization Commission 1945-54; Canberra Times, 1 April 1951). A new organisation was to be created similar in nature to the JO (The Advertiser 13 September 1950). The representatives of each of the three wool-growing countries supported this scheme; however, the Australian Government insisted that involvement was contingent on its growers agreeing to a proposal to be put to them at a referendum on the 23 August 1951. It was rejected by 63,740 votes to 16,310 (McCarthy

\footnotetext{
7 Shareholders in BAWRA voted to wind up the company in December 1922 without debating Higgins' proposal to extend its operations and operate an RPS; The Argus, 7 December 1922, p. 9.
} 
1967; Hitchins nd.) The high price for wool during the Korean War probably influenced growers that a scheme to offset price falls paid for by their levies was unnecessary. They subsequently received a total of $£ 83.7$ million from the return of the $71 / 2$ per cent levy that had been collected during the 1950/51 season and the profits from JO not yet returned to growers (Australia, Commonwealth Bureau of Census and Statistics 1954).

The Australian referendum result in 1951 had important international consequences. Britain and Australia withdrew from the post-JO operation but both New Zealand and South Africa decided unilaterally to proceed with an RPS funded by levies collected from their growers.

In New Zealand, growers and authorities decided to proceed without delay and in 1952 a Wool Commission was created to operate an RPS (Abbott 2013). New Zealand believed that its predominantly coarser wool would allow it to put a floor under prices even without the co-operation of the Australians whose wool was predominantly merino. The funds raised by the sale of the wartime stockpile and contributory charges, $£ 26.596 \mathrm{~m}$, were used to finance the post-1952 scheme by the Wool Commission (Greensmith 1976). Each year a minimum price was set and, if necessary, purchases made in order to maintain the price at a floor. A severe downturn in wool demand in 1966/67, however, created a crisis when the Commission mistakenly raised the reserve price under the pressure of farmer groups just when demand for wool and prices were falling. This meant that prices fell to the floor and the Commission ended up purchasing 645,786 bales of wool, or about 35 per cent of wool offered for auction (Greensmith 1976). Purchases continued into the following season to the extent that by November 1967 the Commission had exhausted its funds and had to borrow from the Reserve Bank of New Zealand to continue purchasing (New Zealand, Department of Statistics 1967, p. 573). As prices subsequently rose the New Zealand authorities were able to clear what was left of the stockpile by 1972/73 (see Figure 1.

In the South African case growers were at first reluctant to proceed on their own. They instead decided that the appropriated balance of wool levies paid by growers in South Africa during the period 1 July 1946 to 30 June 1951 be retained in a Wool Levy Fund under the control of the South African Government's Secretary of Agriculture pending a changed decision on the part of the Australians. ${ }^{8}$ The amount transferred to the new Wool Stabilisation Fund was $£ 6$ million, and in addition, nine large wool stores were also taken over from the JO (Abbott 1997). After 1 July 1955, the fund was augmented by $£ 500,000$ per annum from a wool levy of $1 / 2 \mathrm{~d} / \mathrm{lb}$. paid by growers (Abbott 1997). The downward trend in wool prices late in the 1950s convinced wool authorities in South Africa to initiate a buffer stock price support scheme in March 1958 administered first by the South African Wool Board and then the South African Wool Commission. ${ }^{9}$ The fall in the price of wool relative to the floor price in the early 1970s, see Figure 2 brought about the introduction of a full acquisition scheme in 1972 that operated until 1993.

Over the period 1916 to 1970 , wool price stabilisation schemes were often proposed and argued over in Australia raising the question of what would have been the result of these schemes had they been implemented. The experience of the post-war stockpile schemes (BAWRA and JO) along with the experience of the New Zealand and South African schemes provides some indication, but more detailed analysis of the conditions of the wool industry during the period are required in order to come to firmer conclusions.

\footnotetext{
${ }^{8}$ The share of profits from the sale of South African wool was also included in this Wool Levy Fund. This amounted to $£ 15,570,108$ of which half $(£ 7,785,054)$ was paid to the South African Government (Abbott 1997).

${ }^{9}$ South African Wool Board, Annual Report (1957/58). The average price of greasy wool in South Africa peaked at 175.6 cents/kg in 1950/51 and fell to 105.2 cents/kg in $1956 / 57$ and 60.5 cents/kg in 1958/59.
} 
Large amounts of wool were sold from the stockpiles as part of the post-war stockpile disposal schemes (BAWRA and JO) as shown in Tables 1 and 2. Could growers have done even better if BAWRA and JO had taken more time? Making an assessment depends on estimating the relative size of the demand and supply elasticities for wool. A less elastic demand schedule implies a greater increase in price following a given withdrawal of stock. A less elastic supply schedule implies a lower increase supply in the next period following a price increase. Determining the elasticities of demand and supply required to judge the impact of the stock disposal schemes is not straightforward. Most of the many estimates of elasticities for Australian wool have been made for the post-Second World War period, and while there is a range amongst these estimates, most are inelastic, especially for short and medium term periods (see Table 3; for supply elasticities see Table 4). ${ }^{10} \mathrm{We}$ believe that the lack of substitute fibres such as rayon and polyester in the inter-war period would have reduced demand elasticities relative to those in the post-Second World War period. Following Horner and Philpott (which is the only study that used data from the 1920s and 1930s), we employ a demand elasticity of -0.5 and supply elasticity of 0.5 for the $1920 \mathrm{~s}$ (Horner 1952; Philpot 1955). Taking these elasticities as a benchmark it is possible to use data on BAWRA's activities and new wool and auction prices to analyse the effect of the BAWRA actual and hypothetical wool sales on woolgrowers' income (see Figure 3). It is possible then to make inferences about what the results would have been under alternative assumptions about supply elasticity from Table 4.

Taking the year 1921 as an example, for instance, and using the methods used by Haszler, Chisholm, Edwards and Hone (1996) and Hone and Hope (1994) it is possible to estimate what the impact would have been of releasing no wool from the stockpile in 1921 . In 1921, the sales of wool at auction were 2,725,402 bales of wool (BAWRA 1921). Of this 330,000 was Australian BAWRA owned wool and 470,000 sold by BAWRA on behalf of the British Government (Table 1). The average price received for BAWRA wool in 1921 was $£ 19.37$ per bale, an assumed equilibrium price. The impact of selling wool from the stockpile was twofold; first of all, generating revenue for BAWRA and secondly it reduced the growers' producer surplus by lowering the market price of wool and by reducing the sale of newly produced wool.

If in 1921, BAWRA had not sold any of the BAWRA controlled wool (instead of selling 800,000 bales) then the equilibrium price of wool would have been an estimated average of $£ 27.51 / \mathrm{lb}$ (Figure 3 ). This would have raised the producer surplus to woolgrowers by an estimated $£ 17.3 \mathrm{~m}$, but reduced income to BAWRA from the sale of the wool of $£ 15.5 \mathrm{~m}$, a net gain of $£ 1.8 \mathrm{~m}$. However, not all of the raised producer surplus would have gone to Australian growers, but from the figures, it can be seen that Australian growers would not have been greatly disadvantaged by the non-sale of BAWRA controlled wool. This is a conclusion that is similar to that arrived at by a number of economists studying the disposal of the 1991 stockpile (Hetzler 1994; Hone and Hope 1994; Haszler et al. 1996).

Determining the impact of the stockpile sell off depends assumptions about the demand and supply responses. It is possible that the supply response of woolgrowers would have been less, with the supply elasticity lower than 0.5 (as indicated as possible in Table 4). This would have lowered the price to a lesser degree when stocks were released from the stockpile; and made growers better off. A lower elasticity of demand than -0.5 would have done the opposite, lowered growers' wool prices and income.

\footnotetext{
${ }^{10}$ As wool was released from the stockpile from one year to the next elasticities in the short run or medium run are preferred.
} 
A more feasible hypothetical outcome would have been to release the wool stock at a slower rate than was the case. A slower release would have affected market prices far less and subsequently the producer surplus of growers. As prices fell during the mid to late 1920s the proceeds from the sale of the BAWRA wool would have been less but this would have been more than counterbalanced by higher prices for newly grown wool (regardless of the size of the demand and supply elasticities). Selling wool over a six-year period (1921 to 1926), when wool prices were relatively high, rather than over a two-and-a-half-year period as actually occurred would have generated better returns for growers, a sum of $£ 7.4 \mathrm{~m}$ or nearly an additional twelve per cent, as shown in Table 5. Selling wool from a stockpile from 1926 onwards would have been problematic. World prices then were falling and sales from stocks would have depressed them further. The optimal period was probably to wind things up in 1926 rather than 1923. That said we do have the benefit of hindsight, which BAWRA did not have, but it does help to illustrate just how tricky the whole process is.

The same questions can be raised about the disposal of the stockpile after the Second World War. The sale of large amounts of the JO stockpile wool between 1945 and 1950 would have lowered world wool prices, therefore creating lower grower incomes as the JO profits were more than offset by lower prices. A slower sell off would have allowed a stronger stream of income to growers, while at the same time achieved ample profits from the sale of the stockpiled wool, as wool prices rose higher over a longer period after the Second World War than after the First World War. JO missed the Korean wool boom as its stocks were already exhausted. While the actions taken by JO's administrators failed to optimise grower returns, contemporises considered it a success as an enormous stockpile had been sold at a profit.

Realising an optimal strategy of stock disposals that would have maximised grower incomes would have been difficult given the lack of knowledge of market conditions at the time. Stating, however, that the BAWRA and later the JO were 'successful' because they were able to dispose of large stockpiles quickly, at prices higher than they had been originally paid for the wool, fails to recognise that those administering these schemes might have done even better for the growers, had they released stocks over a longer period, and impacted less on market prices. Arriving at this conclusion indicates that even in favourable conditions operating a wool disposal scheme so as to maximise grower incomes can prove difficult.

\section{IV}

After the winding up of both stockpiles, as discussed earlier, there were disputes about whether RPSs should replace them. In trying to determine the viability of these proposed schemes, it is important to understand what was being proposed. Higgins made a number of proposals in 1922, 1925, and 1931 that some form of organisation be created in the image of BAWRA, which could operate in a similar fashion of holding back wool to reduce price variability the market (Higgins 1925, 1931). None of the proposed schemes provided a fully worked out account of what he came to call the 'central organisation', which could coerce growers to participate, relied on the government, and received its funding from the auction system. Higgins' first proposed scheme in 1922 recommended that wool would be appraised and the growers paid. However, the harvest failed to meet the levels of the last three months of the 1921/22 season. This plan was rejected by BAWRA's shareholders, who voted instead to liquidate the company. Shortly after, at the request of a grazier's association, he suggested the creation of another company owned by the growers that would use the remaining $£ 16$ million of undistributed profits from BAWRA as capital. This proposal was to operate temporarily, for one season. The government would provide initial funding and use its 
powers to prohibit wool exports below the reserve price to ensure that growers could not 'cheat'. As prices rose, the growers lost interest.

The fall in prices in 1925 generated renewed woolgrowers' interest in Higgins' scheme. At the invitation of the Grazier's Federal Council of Australia, he outlined his new scheme at its conference (Australasian Insurance and Banking Record 22 June 1925). This scheme differed sharply from the earlier version in that it was to operate on a permanent basis and the capital to finance purchases of wool which did not realise the reserve price at auction was raised to $£ 50$ million, the equivalent of the current value of the clip. The capital was to come from bank loans guaranteed by the government until a levy on growers of five per cent of the price of wool would raise sufficient funds. Higgins underestimated the difficulty in raising this capital as it would have stretched the lending capacity of the Australian trading banks at the time; the loan being the equivalent of 23 per cent of all bank loans. Moreover, the federal government, which was to be the ultimate guarantor, had limited fiscal resources. ${ }^{11}$ Higgins blithely suggested that the governments of Britain, New Zealand, and South Africa should be asked to underwrite the venture with an 'Empire guarantee' (Australasian Insurance and Banking Record 21 July 1925). Perhaps trying to assuage critics of earlier proposals, Higgins stated that the scheme had modest ambitions compared to the 1922 proposal, which was to cover all farm products.

The 1925 proposal, he argued, would not 'artificially set' minimum prices and it would be operated in such a fashion so as not lead to an accumulation of stocks from season to season, however, his opponents did not believe this (Australasian Banking and Insurance Record 21 July 1925). Higgins did not disclose his thoughts about the mechanism for setting a reserve price.

We examine the effects of a series of possible reserve prices using wartime purchase prices as a floor. The first simulation, as shown in Figure 4, sets the reserve price at the wartime purchase price of $16.5 \mathrm{~d} / \mathrm{lb}$ per greasy wool. We judge that anything lower would have been unacceptable to growers. ${ }^{12}$ The outcome of having this reserve can be estimated, using assumed price elasticity of demand of -0.5and of supply of 0.5 . From Figure 4 it can be seen that the average export value of greasy wool peaked in the year 1924/25 and then tended to slide, reaching the wartime average in 1928/29. As late as $1927 / 28$ the average value was still above the wartime average, and well in excess of the average in the previous worst postwar years of 1920/21 and 1921/22, when BAWRA was urged to take wool off the market. The 1928/29 average price, however, was well below the wartime average. To lift the price from $11.3 \mathrm{~d} / \mathrm{lb}$ to $16.5 \mathrm{~d} / \mathrm{lb}$ would have required a purchase of 240 million $1 \mathrm{~B}$ of wool. Purchasing 240 million $\mathrm{lB}$ at $16.5 \mathrm{~d} / \mathrm{lb}$ would have cost an RPS authority $£ 24.2$ million (see Table 6 below). In the following year defending the $16.5 \mathrm{~d}$ reserve price, when the market price had fallen further to $9.16 \mathrm{~d} / \mathrm{lb}$, would have required a purchase of 560 million $\mathrm{lB}$ at a value of $£ 38.5$ million, assuming the same elasticities. The RPS would have exhausted its funds attempting to defend this low base reserve price.

It is quite possible that the authority would have been pressured by growers to raise the reserve price in the mid-1920s, as the pressure applied by growers wanting higher prices

\footnotetext{
11 The amount of outstanding government loans owned by the Commonwealth Bank of Australia and private trading banks was $£ 219 \mathrm{~m}$ in 1925 . The figure had risen to $£ 267 \mathrm{~m}$ by 1931 (Butlin et al., 1971, Tables 1 and 29 , 112 and 374). The revenues of the federal government were only $£ 67.6 \mathrm{~m}$ in 1925 and $£ 69.6 \mathrm{~m}$ in 1931 (Barnard, 1987, GF 8-14).

${ }^{12}$ Most discussion at the time as about a reserve price being set at a 'reasonable level'. The National Council of Woolbrokers discussed a proposed 'reserve' as the 'average price of the last three months of the 1921/22 season', which have put it at above the wartime level (National Council of Wool Selling Brokers of Australia,. 29/8/1922).
} 
rose over time. The number of growers with smallish holdings who combined sheep husbandry with wheat and dairy farming rose from a minority in the inter-war years to a clear majority after the Second World War. The political influence of this group was amplified by the key role of the Country Party in conservative governments from the 1920s, and the importance of the radical woolgrowers whose organisations coalesced into the Associated Meat and Wool Producers' Federation in 1939.

Du Plessis recognised that such an RPS provided both the temptation and capacity to increase swings in the price of wool. He questioned whether the directors of Higgins' 1925 organisation would have had the necessary information and skill to set a reserve price that was not too far from the market. For an organisation managing such a large percentage of the world's wool to make an error of judgement in this regard could he argued: 'mean an absolute catastrophe', (Du Plessis 1931, p. 236). Furthermore setting the reserve too high would result in an unnecessarily large accumulation of stocks, encourage further production and ultimately force this wool back onto an oversupplied market. The greatest danger he argued would arise from the 'very strong temptation to manipulate prices by means of withholding stocks from the market. It is very difficult to have power and not use that power for interested purposes' (Du Plessis 1931, p. 235). Moreover, there would be an almost irresistible pressure, particularly in an organisation controlled by woolgrowers, to 'try and maintain prices above the cost of production' (Du Plessis 1931, p. 239). Bridgen also highlighted the dangers facing those managing such a scheme once prices continued to fall saying: 'it is at such times that control fails, for the producers refuse to believe the facts. There is no proof to convince them'. 13

The war-time price of $16.5 \mathrm{~d} / \mathrm{lb}$ is a conservative choice for a reserve price. It was nearly 40 per cent below the $1924 / 25$ price in nominal value and more still in real terms. An alternative is to follow Dyason (1928), and take the war price plus the profits from BAWRA, which he estimates as being $18.94 \mathrm{~d}$ per $\mathrm{lb}$, and finally to take the war price plus all profits on Australian wool owned by BAWRA and the British which lifts the return to $22.38 \mathrm{~d}$ per $1 \mathrm{~b}$. Results from this approach to determining possible reserve prices are shown in Figure 4 and Table 6. In each case, attempting to maintain these higher reserve prices would have created an insurmountable burden on a central wool authority and more quickly exhausted the capital of such an organisation. For instance, in 1928/29 and 1929/30 it would have cost $£ 69$ million and $£ 93$ million, respectively to maintain prices that were double that of the depression era prices. All of these higher prices as 'reserve' would have driven the scheme into ruin very quickly.

During the depression, prices fell considerably for wool but the quantity of wool supplied did not change much, as woolgrowers had no real alternatives to growing wool as all agricultural prices were depressed. In these circumstances, the elasticity of supply might, therefore, have been less than 0.5 (this is also implied in the figures in Table 4). If this was the case, then an RPS would not have needed to purchase quite so much wool to keep prices high. One problem with assuming an inelastic supply curve based on depression level data is that it is also quite possible that the supply curve was kinked, inelastic with falling prices, and more elastic with rising prices. This might have been the case if non-woolgrowers would have been attracted into the industry if prices had been kept above their actual levels, a not unreasonable assumption. Table 6 provides estimates of the purchases needed to maintain the alternative reserve prices if the supply elasticity had been either 0.2 or zero. The figures in Table 6 imply that, whatever the case, even with a perfectly inelastic supply cure, an RPS would have exhausted its financial reserves by 1932, leaving the industry with a heavy debt

${ }^{13}$ Australia, Report of the Commonwealth Wool Inquiry Committee, Addendum No. 1, para 32, 57. 
burden, considerable interest payments to make, a sizeable wool stockpile sell off during the mid to late 1930s and, presumably, a considerable political controversy over the conduct of the scheme.

If the elasticities had been higher, this would not have altered significantly the result of the scheme, simply its longevity. Assuming a higher demand elasticity of -1.0 , for instance, would have required expenditure of around one-half of that with an elasticity of 0.5 . In that case, in 1928/29 the expenditure necessary would have been $£ 12.1$ million (compared to $£ 24.2$ million with a demand elasticity of -0.5 ). In the following year, 1929/30, defending the $16.5 \mathrm{~d}$ reserve price, would have required an expenditure of $£ 19.24$ (compared to $£ 38.5$ million). These sums were still considerable and would have meant the exhaustion of the reserve fund perhaps a year or two later than if the elasticity was -0.5 .

It is possible that a lower reserve price might have been selected or that a new much lower one been used in the face of declining prices. There is, however, evidence that the wartime price was one that was heavily expected by woolgrowers as being the "normal" price and one that prices should not be allowed to fall below. Placing the price below it would have been difficult, and Higgins always expressed the view that should be defended. There is also evidence that, at least, initially woolgrowers would have expected prices to bounce back, and so would have acted to defend pries.

Overall, the impact of the depression on demand for wool and prices was just too large for an authority to manage, given the sorts of financial resources that were being discussed about in the mid to late 1920s. Higgins had believed that around $£ 50$ million would have been enough to smooth out the fluctuations in demand and prices, whereas our results imply that a sum of around $£ 200$ million would have been actually required. Even with a sum of this magnitude setting a forward-looking floor price would have been difficult even under the implausible assumption that an authority could have maintained its independence from industry pressures. Finally, it is pretty certain that any wool authority tasked with attempting to maintain a floor price would not only have been swept away by the depression, but also its conduct would have attracted considerable controversy regardless of how efficiently its operations were carried out. What occurred then was that the acceptability of organised growing amongst some woolgrowers was maintained, both because the wool stockpile was disposed of at a time of high prices (1921-23) and because no scheme was in operation during a period of collapsing prices (1927-33). In the latter case, a failed scheme might have significantly dampened the enthusiasm by woolgrower interests for agricultural price support schemes, just as it did after the collapse of the later scheme in 1991.

\section{$\mathrm{V}$}

If a hypothetical inter-war RPS would likely have imploded, might a different result have occurred after the Second World War? Could the scheme's administrators resist grower pressure to lift the reserve and display greater skills in forecasting the world's supply and demand for wool? In the drawn out negotiations to extend the life of the JO, British interests seemed to hold sway in how the reserve price would be determined (McCarthy 1967). The purpose of the RPS was to offer only temporary relief against sharp falls in price and was not to be used to lift prices above the long-term trend of the market. The reserve prices set during JO's operations were far below the rapidly rising market price of wool (White 1982). However, Britain's influence evaporated as the 1951 Australian referendum defeat unravelled the proposal. We use the New Zealand and South African statutory bodies' reserve price setting as a proxy for their political and technical skills. What lessons does their experience teach us about Australia's likely behaviours? Both New Zealand and South Africa began with modest reserve price policies set well below the highs of 1950 and 1951, 
but above the prices used by JO between 1945 and 1951. In 1960/61, the New Zealand and South African average reserves were about equal at NZ 61 cents $/ \mathrm{kg}$ and SA 62 cents $/ \mathrm{kg}$ (76 and 77 Australia cents/kg respectively). The New Zealanders, however, raised their reserve price in the early to mid-1950s, and again in the mid-1960s, which created some subsequent problems (Figures 1 and 2).

Would Australia have made similar decisions with respect to setting reserve prices if it had established an RPS the 1950s or 1960s? In 1950/51, the Australian average reserve under the JO scheme was $23.3 \mathrm{~d} / \mathrm{lb}$ (equivalent of 53.3 cents $/ \mathrm{kg}$ ), well below the current market. However, higher wool prices in the early 1950s encouraged both the New Zealanders and the South Africans to lift their reserve prices above that of the last year of the JO. They also did so independently of the wishes of the British representatives who constituted half of the members of JO's Board. New Zealand set its reserve at $44 \mathrm{NZ}$ cents $/ \mathrm{kg}$, or 55 Australian cents $/ \mathrm{kg}$ in 1952/53, and progressively raised to a peak of $66 \mathrm{NZ}$ cents $/ \mathrm{kg}$ in 1966/7 (or 82 Australian cents $/ \mathrm{kg}$ ). The South Africans followed in 1957/58 with a reserve of 62 SA cents $/ \mathrm{kg}$, or 77 Australian cents $/ \mathrm{kg}$. It is reasonable to assume, given the growing influence of growers wanting a RPS, that Australia's RPS would have fallen in the range between the JO and as the South African price of 77 Australian cents $/ \mathrm{kg}$ (referred to as Reserve Price A). They might also have increased the reserve price to the New Zealanders' reserve of Australian 82 cents/kg - referred to as Reserve Price B) (see Figure 5, Table 7A).

Pre-war critics raised concerns about the political pressure that growers would bring on the administrators of an RPS to shift from smoothing the market to forcing higher prices. The political power of growers anxious to raise prices rose strongly from the late 1930s, as their representatives were given membership to the Australian Wool Commission (Merrett and Ville 2016). The growers did not always get what they wanted despite their growing political influence and increased government financial commitment to the industry. The Australian RPS introduced in 1970 required cabinet approval with respect to setting a reserve price. From November 1970, the Wool Commission had defended a reserve price of 29 cents/lb (64 cents/kg) (Canberra Times 23 July 1971). In July 1971, an Australian Cabinet decision was made to set the average minimum price at 36 cents $/ \mathrm{lb}$ (79 cents $/ \mathrm{kg}$ ) for the 1971/72 season (Canberra Times 23 July 1971). Industry organisations such as the Australian Woolgrowers and Graziers Council and the Australian Wool and Meat Producers Association requested a reserve of 40 cents/lb (88 cents/kg) (Canberra Times, 11 June 1971). This position was favoured by the Country Party in Cabinet, led by the redoubtable Jack McEwen, but defeated by the Liberal Party majority. However, a consolation deficiency payment was made by the Australian Government to growers to reach 36 cents/lb. Thus the 88 cents $/ \mathrm{kg}$, would appear to have been the highest possible reserve price seriously considered at the time (referred to as Reserve Price D in Table 7B), with the 79 cents $/ \mathrm{kg}$ being the more likely to have been defended had a scheme been in place during the $1960 \mathrm{~s}$ (referred to as Reserve Price C in Table 7B).

We have identified four possible reserve prices, 77, 79, 82 and 88 cents per kilo (Table 7A and 7B. The relationship between the average price of wool and the reserve from the early 1950s until the early 1970s is shown in Figure 3 (with Reserve Prices C and D). Market prices were above the reserve price range until the late 1960s. We have chosen a reserve price of 79 cents as the most feasible. Table $7 \mathrm{~B}$ provides estimates of the amounts of wool needed and funds expended to maintain this floor by a hypothetical Australian RPS. We 
estimate that the capital of the RPS would have been $\$ 150 \mathrm{~m}$ by the late $1960 \mathrm{~s} .{ }^{14}$ The downturn in the price of wool in 1958/59 would have required some small purchase in as happened in New Zealand and South Africa. The relatively minor purchases followed by a quick rebound in prices would have most likely have reinforced faith in an RPS. However, more serious problems lay ahead as the price of wool fell below the reserve in the early 1970s. The funds available to support the RPS at $77 \mathrm{c} / \mathrm{kg}$ would have been approximately expended in the years 1970/71 and 1971/72, \$124m and \$35m respectively. Maintenance of the RPS would probably have required a capital injection from the government. These would have been short lived, as rebounding prices would have enabled a profitable sale of the stockpile.

If a reserve price of 88 cents, the figure pressed for by the growers in 1971, had been in the place, the RPS's funds expended during 1968/69 and 1969/70 would have been $\$ 108 \mathrm{~m}$. As another $\$ 204 \mathrm{~m}$ would have been required in 1970/71, the scheme would have had to be suspended, unless the government injected more funds or the reserve price was reduced. A large stockpile would have eventuated, which could have been disposed over as prices rose again. However, these events would have seriously injured the standing of the RPS mechanism and would have dampened the enthusiasm for what was to come.

\section{VI}

This paper uses economic analysis to simulate the possible impact of wool stock disposal and buffer stock schemes in the inter-war and post-war periods. Our simulations rely on assumptions about demand and supply elasticities and possible reserve price levels. ${ }^{15} \mathrm{We}$ test if the post-First World war and Second World War stock disposal schemes optimised grower incomes and examine the likely results of possible stabilisation schemes in the interwar and post-Second World War periods.

Our estimates suggest that in the immediate post-First World War era, Australian growers could have received higher prices for wool if BAWRA had place its stocks on the market more slowly. The strategy pursued by BAWRA seriously underestimated the inelasticity of demand for wool, and depressed market prices more than necessary. Although a slower sale of wool from the stockpile would have meant that BAWRA generated less revenue from its own sales, the income to woolgrowers overall would have been higher. This result is at odds with contemporary views and later writings by commentators about wartime and post-war interventions (Scott 1936; Dyason 1928; Sims nd.; Hitchins nd.; Fyfe 1996). With the exception of Brigden and White, those writing about its action are unanimous in their praise of the outcome (Brigden 1932; White 1982). Indeed, the 'success' of BAWRA was a powerful force in garnering support for the idea in the 1920s of having an RPS which would draw heavily on the same organisational structure.

Moreover, we establish that under any set of reasonable assumptions that the RPS proposed by Higgins in 1925 would have collapsed in the 1930s and a cash-strapped government could not have 'bailed' out the industry. In collapsing, it would also have generated a considerable fiscal challenge to the government of the day, heightened the levels of dispute within the industry, and subsequently reduced support for later proposed schemes.

\footnotetext{
${ }^{14}$ It had been advocated to use the left over JO money ( $\$ 58.75$ million or $\$ 117.5$ million) to start an Australian RPS. These funds would have appreciated in value over time, perhaps to around $\$ 150 \mathrm{~m}$ when the fund would have been used in the late 1960s.

${ }^{15}$ This is true of any modelling exercise of this sort and a disagreement about these assumptions was the source of some dispute about the best method of disposing of the post-1991 stockpile.
} 
Post-Second World War policy makers made several poor decisions. First, JO rushed the sale of the large stockpile so growers missed out on the exceptionally high prices during the Korean wool boom. The growers increasingly pressed for the introduction of an RPS, and their aims were partially achieved in 1967 and then in full from 1970. In particular, the fall in wool prices in the late 1960s would have put a considerable strain on the financial resources of any wool authority. Just how substantial this strain would have been depended on the level of price that the wool authority attempted to defend. If, for instance, the reserve price had been established at the level favoured by the Country Party and associated farm bodies, 88 cents, the scheme would most likely have collapsed.

In the light of our research, therefore, the decisions to not create RPS schemes after the First World War and Second World War were probably fortuitous ones. The decades of the 1920s, 1930s, 1950s and 1960s were ones of declining wool prices, after the peak of postwar wool booms. In such periods of steadily declining wool prices, the operation of price support schemes would have entailed growing degrees of risk. In many ways the 1970s and 1980s, the period when an RPS was operated, was a relatively more benign as wool prices were generally rising. ${ }^{16}$

Overall, the results of this study indicate that operating a wool stabilisation scheme in the inter-war and post-wars years would have been problematic. Wool prices over the longer term fluctuate widely and distinguishing between short-term downturns and longer-term structural shifts is very difficult. As one commentator put it:

During the period under review, nearly all forecasters of wool prices failed to predict even the direction of change.... The history of the wool market during the late forties and early fifties gives little ground for confidence in forecasts of wool prices (Little 1967, pp. 181, 182).

Given the degree of knowledge about markets conditions at the time, it would have been difficult for a central authority to develop strategies that consistently maximised grower income. This means that operating any scheme that tries to stabilise prices faces periodic instances of risk and financial strain.

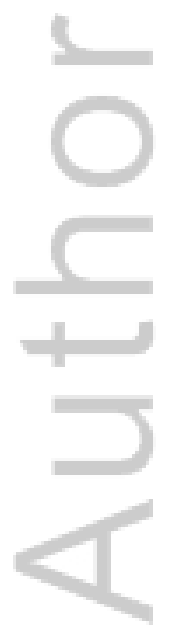

\footnotetext{
${ }^{16}$ The average price of Australian greasy wool rose from 34.3 cents $/ \mathrm{kg}$ in 1972/73 to 83.1 cents $/ \mathrm{kg}$ in 1977/78, to 120.3 cents/kg in $1982 / 83$ and 179.8 cents/kg in 1987/88 (ABARE 1989).
} 


\section{REFERENCES}

Abbott, M.J. (1997) South African wool marketing. South African Journal of Economic History, 12(1-2): 1-25.

Abbott, M.J. (2013) Market support schemes and their interaction: the case of the wool industry. Agrekon, 52(3): 63-82.

Abbott, M., and Ahmed, A. (1999) The South African wool supply response. Agrekon, 38(1): 90-105

Australasian Insurance and Banking Record (Sydney: McCarron Bird).

Australia, Commonwealth Bureau of Census and Statistics (1918-51) Official Year Book of the Commonwealth of Australia (Melbourne: Commonwealth Bureau of Census and Statistics).

Australia, Commonwealth Wool Inquiry Committee (1932) Report by Commonwealth Wool Inquiry Committee. Commonwealth Parliamentary Papers, 1932/34, IV, 769-870.

Australian Bureau of Agricultural and Resources Economics (ABARE) (1990) Australian Commodity Statistics (Canberra: ABARE).

Australian Wool Corporation (1976) Annual Report (Parkville: AWC).

Australian Wool Realization Commission (1945-54) Verbatim Notes of Proceedings, Australian Wool Realization Commission Meetings, MP136/18 (Melbourne: Australian Archive).

Bailey, J. D. (1966) A Hundred Years of Pastoral Banking: A History of the Australian Mercantile Land and Finance Company 1863-1963 (Oxford: Clarendon Press).

Barnard, A. (1987) Government finance. In: W. Vamplew, ed. Australians: Historical Statistics (Broadway: Fairfax, Syme \& Weldon Associates).

Blau, G. (1946) Wool in the world economy. Journal of the Royal Statistical Society, 109(3): 179-242.

British Australian Wool Realization Authority (BAWRA) (1921-26) Report and Statements of Accounts...Annual Report (Melbourne: The Association).

Brigden, J. B. (1932) The marketing of wool. Addendum to: Australia, Commonwealth Wool Inquiry Committee, Report by Commonwealth Wool Inquiry Committee. Commonwealth Parliamentary Papers, 1932/34, IV, 769-870.

Butlin, S. J., Hall, A. R., and White, R.C. (1971) Australian Banking and Monetary Statistics, 1817-1945, RBA Occasional Paper 4A (Sydney: RBA).

Campbell, K.O. (1980) Australian Agriculture: Reconciling Change and Tradition (Melbourne: Longman Cheshire).

Campbell, R., Gardiner, B., and Haszler, H. (1980) On the hidden revenue effects of wool price stabilisation in Australia: initial results. Australian Journal of Agricultural Economics, 24(1): 1-15.

Canberra Times (Ainslie, ACT: C.J. Shakespeare for the Federal Capital Press of Australia Ltd).

Cashin, P., Liang, H., and McDermott, J. (1999) Do commodity price stocks last too long for stabilization schemes to work? Finance and Development, 36(3): 40. 
Du Plessis, A. F. (1931) The Marketing of Wool (London: Sir Isaac Pitman \& Sons).

Dyason, E. C. (1928) BAWRA, Economic Record, IV, Supplement, Marketing Primary Products with special reference to Australia and New Zealand, 95-104.

Fyfe, C. (1996) Gentlemen's Agreements, Australian Wartime Wool Appraisements (Dalkeith WA: Lana Press).

Gilbert, C.L. (1996) International commodity agreements: an obituary notice. World Development, 24(1): 1-19.

Greensmith, E.L. (1976) The New Zealand Wool Commission (Wellington: New Zealand Wool Marketing Corporation).

Gruen, F.H. (1964) Some hidden gains and losses of a wool reserve scheme. Australian Journal of Agricultural Economics, 8(2): 181-188.

Haszler, H., Chisholm, A., Edwards, G., and Hone P. (1996) The wool debt, the wool stockpile and the national interest: did the Garnaut Committee get it right? Economic Record, 72(218): 260-71.

Hertzler, G. (1994) Coordinating production and disposal of commodity stockpiles with application to Australia's wool industry. Australian Journal of Agricultural Economics, 38(1): 49-76.

Higgins, Sir John (1922) Address, in Melbourne, on 29 $9^{\text {th }}$ August, 1922, at a conference of representatives of the Australian wool industry (Melbourne: Sands \& McDougall).

Higgins, Sir John (1925) Address/delivered by Sir John Higgins at a conference of woolgrowers held in Melbourne 23rd June 1925 (Melbourne: privately published).

Higgins, Sir John (1931) The stabilisation or the equalisation or the insurance of wool values, address delivered to The Empire Wool Conference (Melbourne 22 June 1931: privately published).

Hitchins, F. Eric (nd), Tangled Skeins (Melbourne: Roberston \& Mullens Ltd).

Hone, P., and Hope, A. (1994) Marketing our way out of the wool problem: the myths and realities. Economic Papers: a Journal of Applied Economics and Policy, 15(2): 65-79

Horner, F.B. (1952) The pre-war demand for wool. Economic Record, 28 (54): 13-28.

Houthakker, H. S. (1967) Economic Policy for the Farm Sector (Washington: American Enterprise Institute for Public Policy Research)

Imperial Economic Committee (1928-39) Wool Production and Trade (London: HMSO).

Keneley, M. J. (2001) Woolgrowers, brokers and the debate over the sale of the Australian wool clip, 1920-25. Australian Economic History Review, 41(1): 35-55.

Keynes, J.M. (1942) On commodity control. In D. Moggeridge, ed., Collected Writings of John Maynard Keynes, Vol. XXVII, Activities 1940-46 Shaping the Post War World: Employment and Commodities (London: MacMillian).

Little, A.J. (1967) Aspects of the world wool market 1939-52. Australian Economic Papers, 5(8): 165-82.

Lloyd, A. G. (1965) Reserve price scheme for wool - A defence. Economic Record, 41 (96): 505-22.

McCarthy, E. (1967) Wool Disposals 1945-52: the Joint Organization (London: Hobbs). 
Merrett, D., and Ville, S. (2016) Too big to fail; explaining the timing and nature of intervention in the Australian wool market, 1916-1991. Australian Journal of Politics and History, 62(3): 337-352.

National Council of Wool Selling Brokers of Australia (1918-23) Minutes (Sydney: The Council).

New Zealand, Department of Statistics (1946-74) New Zealand Official Year-Book (Wellington: Department of Statistics).

New Zealand Wool Board (1991) Annual Report (Wellington: Wool Board).

New Zealand Wool Commission (1952-74) Report and Statement of Accounts (Wellington: Wool Commission).

Newbery, D. M. G. and Stiglitz, J. E. (1981) The Theory of Commodity Price Stabilization A Study in the Economics of Risk (Oxford: Oxford University Press).

Parish, R. M. (1964), The Wool Board's report on marketing. The Australian Quarterly, 36(3): 9-18.

Powell, A. A., and Campbell, K. O. (1962) Revenue implications of a buffer-stock scheme with an uncertain demand schedule, Economic Record, 38 (83): 373-85

Philpott, B. P. (1955) Fluctuations in wool prices, 1870-1953. Yorkshire Bulletin of Economic and Social Research, 7(1): 1-28.

Queensland Country Life (Brisbane: Rural Press Group).

Salant, S.W. (1983) The vulnerability of price stabilization schemes to speculative attack. Journal of Political Economy, 91(1): 1-38.

Scott, R. C. (1936) The Rugging of Sheep for Wool Improvement (Adelaide: Dept. of Agriculture of South Australia).

Sims, H. (nd) A Message from BAWRA (Sydney: Endeavour Press).

South Africa (1961) Report of the Controller and Auditor-General on the accounts of the South African Wool Commission, 1960/61 (Pretoria).

South African Wool Board (1951-74) Annual Report (Pretoria: Wool Board).

Sturgess, I. M. (1968) The Wool Board's second Report on Marketing: A review article. Australian Journal of Agricultural Economics, 12(2): 16-34.

South Africa, Wool Commission (1960-74) Annual Report (Port Elizabeth: Wool Commission).

Standing Committee on Agriculture (1980) Statutory Marketing Authorities of Australia: A Compendium (Melbourne: SCA Technical Report Series, No. 9, CSIRO).

Sydney Morning Herald (Sydney: Charles Kemp and John Fairfax).

The Advertiser (Adelaide: Advertiser Newspapers Ltd).

The Argus (Melbourne: Argus Office).

Tsokhas, K. (1990) Markets, Money and Empire: The Political Economy of the Australian Wool Industry (Melbourne: Melbourne University Press).

Turnell, S. (1998) The quest for commodity price stability: Australian economists and 'buffer stocks'. Macquarie Economics Research Papers, No. 98/10 (Sydney: Macquarie University). 
White, L. (1982) Wool in Wartime: a Study in Colonialism. (Sydney: Alternative Publishing Co-operative Ltd.).

Williams, J.C. and Wright, B.D. (1991) Storage and Commodity Markets (Cambridge: Cambridge University Press).

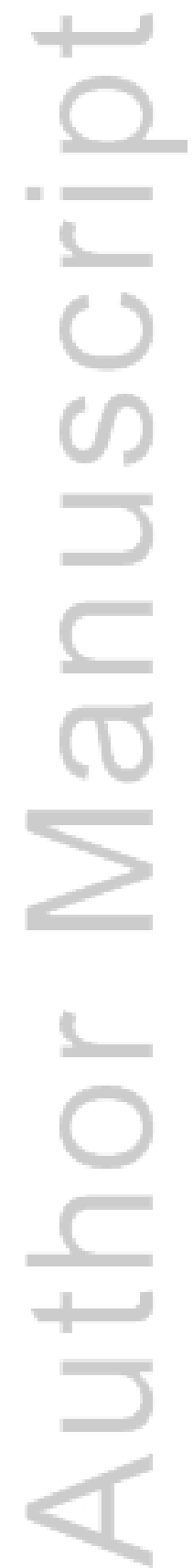

This article is protected by copyright. All rights reserved. 
Table 1: Stocks and sales of BAWRA wool

\begin{tabular}{|c|c|c|c|c|c|c|}
\hline & $\begin{array}{c}\text { Stocks } \\
\text { 1-Jan-21 } \\
\text { bales }\end{array}$ & 1921 & 1922 & $\begin{array}{l}1923 \\
\text { bales }\end{array}$ & $\begin{array}{c}1924 \\
\text { to } 2 \text { May } \\
\text { bales }\end{array}$ & $\begin{array}{l}\text { Total } \\
\text { bales }\end{array}$ \\
\hline \multicolumn{7}{|l|}{ Australia } \\
\hline Merino & 904,180 & 484,031 & 345,710 & 73,694 & 89 & 903,524 \\
\hline Crossbred & 931,825 & 176,199 & 274,632 & 319,146 & 162,297 & 932,274 \\
\hline \multicolumn{7}{|l|}{ New Zealand } \\
\hline Merino & 3,181 & 449 & 267 & 2,333 & 132 & 3,181 \\
\hline Crossbred & 769,762 & 138,441 & 275,855 & 308,428 & 47,069 & 769,793 \\
\hline Falkland Islands & 2,329 & & & & & 2,329 \\
\hline SA (1 Jan 1922) & 80,550 & & 80,655 & & & 80,655 \\
\hline Total & $2,691,827$ & 799,120 & 977,119 & 703,601 & 209,587 & $2,691,756$ \\
\hline
\end{tabular}

Source: Australia, Commonwealth Bureau of Census and Statistics, Official Year Book (1921-25). BAWRA (1921-26).

This article is protected by copyright. All rights reserved. 
Table 2. Stocks of the Joint-Organization's wool, 1945 to 1951, bales

\begin{tabular}{|l|c|c|c|c|c|c|c|}
\hline & 1945 & 1946 & 1947 & 1948 & 1949 & 1950 & 1951 \\
\hline & $1-J u l-45$ & $1-J u l$ & $1-J u l$ & $1-J u l$ & $1-J u l$ & $1-J u l$ & $1-J u n$ \\
\hline & bales & bales & bales & Bales & bales & bales & Bales \\
\hline Australia & $6,796,000$ & $3,789,200$ & $3,076,000$ & $2,320,000$ & $1,254,290$ & 376,100 & 11,856 \\
\hline NZ & $1,777,000$ & $1,425,100$ & $1,092,000$ & $1,092,000$ & 410,883 & 103,800 & 6,000 \\
\hline SA & $1,834,000$ & 572,200 & 347,000 & 347,000 & 35,313 & 1,500 & 0 \\
\hline Total & $10,407,000$ & $5,786,500$ & $4,515,000$ & $4,515,000$ & $1,700,486$ & 481,400 & 17,856 \\
\hline
\end{tabular}

Source: Australia, Commonwealth Bureau of Census and Statistics, Official Year Book (1945-51). McCarthy (1967).

This article is protected by copyright. All rights reserved. 
Table 3: Estimates of wool demand elasticities

\begin{tabular}{|l|l|l|l|l|}
\hline Author(s) & & $\begin{array}{l}\text { Short } \\
\text { term }\end{array}$ & $\begin{array}{l}\text { Medium } \\
\text { term }\end{array}$ & $\begin{array}{l}\text { Long } \\
\text { term }\end{array}$ \\
\hline Horner 1952 & UK, USA & -0.50 & na & na \\
\hline Philpott 1955 & UK & -0.46 & na & na \\
\hline BAE 1967 & UK & -0.26 & na & na \\
\hline IAC 1976 & UK & -0.28 & na & na \\
\hline Campbell, Gardiner and Haszler 1980 & OECD & -0.12 & na & na \\
\hline AWC-BAE 1987 & OECD & -0.23 & -0.80 & na \\
\hline Ball, Beare, Harris 1989 & USA, Europe, Japan & -0.10 & -0.37 & -0.70 \\
\hline Harris and Shaw 1990 & Australian wool & -0.45 & -1.93 & -1.95 \\
\hline Connelly 1992 & Australian wool & -0.50 & -0.87 & -0.95 \\
\hline Zeitsch and Lawrence 1990 & Australian wool & -0.59 & na & -1.46 \\
\hline O'Donnell 1992 & UK fibre & -0.53 & na & na \\
\hline
\end{tabular}

Note: Short term is either the instantaneous response or response after one year. Medium term is the response over a period of up to five years.

This article is protected by copyright. All rights reserved. 
Table 4: Estimates of wool supply elasticities

\begin{tabular}{|l|l|l|l|}
\hline Author $(s)$ & Short term & Medium term & Long term \\
\hline Powell and Gruen 1967 & 0.07 & 0.33 & na \\
\hline Witherell 1969 & 0.07 & 0.13 & na \\
\hline Wicks and Dillon 1978 & 0.25 & 0.36 & na \\
\hline Vincent, Dixon and Powell 1980 & na & 0.26 & na \\
\hline Meikle, Smith and Smith 1981 & 0.09 & na & na \\
\hline Adams 1984 & na & 0.46 & na \\
\hline Hall and Menz 1985 & na & 0.35 & na \\
\hline Dewbre, Shaw, Corra and Harris 1985 & 0.04 & 0.35 & 0.86 \\
\hline Findlay, Dewbre andd Geldard 1989 & 0.10 & 0.36 & na \\
\hline Harris and Shaw 1990 & 0.00 & 0.22 & 0.79 \\
\hline Connolly 1992 & 0.04 & 0.45 & 0.62 \\
\hline Kokic, Beare, Topp and Tulpule 1993 & na & 0.45 & na \\
\hline Abbott and Ahmed 1999 & na & 0.10 & na \\
\hline
\end{tabular}

Note: Short term is either the instantaneous response or response after one year. Medium term is the response over a period of up to five years.

This article is protected by copyright. All rights reserved. 
Table 5: Hypothetical price and quantity of wool sold assuming BAWRA/UK stockpile sold over six years (1921 to 1926)

\begin{tabular}{|c|c|c|c|c|c|c|c|}
\hline & $\begin{array}{c}\text { Actual } \\
\text { quantity } \\
\text { exported } \\
\text { bales }\end{array}$ & $\begin{array}{c}\text { Actual } \\
\text { BAWRA/ } \\
\text { UK wool } \\
\text { sold bales }\end{array}$ & $\begin{array}{c}\text { Actual } \\
\text { wool } \\
\text { price } \\
£\end{array}$ & $\begin{array}{c}\text { Hypothetical } \\
\text { quantity }\end{array}$ & $\begin{array}{c}\text { Hypothetical } \\
\text { price }\end{array}$ & $\begin{array}{c}\text { Actual } \\
\text { BAWRA \& } \\
\text { UK revenue } \\
£\end{array}$ & $\begin{array}{c}\text { Hypothetical } \\
\text { BAWRA \& } \\
\text { UK revenue } \\
£\end{array}$ \\
\hline & a & $\mathrm{b}$ & $\mathrm{c}$ & $\mathrm{d}$ & $\mathrm{e}$ & $\mathrm{f}$ & $\mathrm{g}$ \\
\hline 1921 & $2,725,402$ & 801,449 & 19.37 & $2,628,953$ & 22.05 & $15,524,067$ & $10,363,500$ \\
\hline 1922 & $4,818,439$ & 977,119 & 23.17 & $4,546,320$ & 25.90 & $22,639,847$ & $12,173,000$ \\
\hline 1923 & $3,893,357$ & 832,115 & 23.35 & $3,766,242$ & 25.74 & $19,429,885$ & $12,097,800$ \\
\hline 1924 & $3,241,466$ & 209,614 & 30.83 & $3,736,852$ & 28.54 & $6,462,400$ & $13,413,800$ \\
\hline 1925 & $3,175,215$ & 0 & 34.98 & $3,880,215$ & 30.47 & 0 & $14,320,900$ \\
\hline 1926 & $4,429,933$ & 0 & 21.73 & $5,135,379$ & 19.34 & 0 & $9,095,544$ \\
\hline & & $2,820,297$ & & & & $64,056,199$ & $71,464,544$ \\
\hline
\end{tabular}

Note: Hypothetical quantity estimated assuming 470,000 bushels per year over six years

Numbers in Columns a, b, c are taken from Australia, Commonwealth Bureau of Census and Statistics, Official Year Book.

Hypothetical equilibrium quantity $=($ actual exports-change in BAWRA sales $)+(470,000 / 2)$ $\mathrm{d}=[\mathrm{a}-(\mathrm{b}-470,000)]+(470,000 / 2)$

Hypothetical price $=$ Actual price $+[(\%$ change in equilibrium quantity $) \times$ Actual price $]$ $\mathrm{e}=\mathrm{c}+[100 *(\%$ change in equilibrium quantity) $\mathrm{x} \mathrm{c}$

Actual BAWRA \& UK revenue $=$ Actual sales $\mathrm{x}$ price $=\mathrm{b} \times \mathrm{c}$

Hypothetical BAWRA \& UK revenue $=470,000 \mathrm{x}$ Hypothetical price $=407,000 \mathrm{x}$ e .

This article is protected by copyright. All rights reserved. 
Table 6: Hypothetical sums required to maintain the alternative average prices of wool

\begin{tabular}{|c|c|c|c|}
\hline & $\begin{array}{c}\varepsilon_{\mathrm{d}}=0.5 \\
\varepsilon_{\mathrm{s}}=0.5\end{array}$ & $\begin{array}{c}\varepsilon_{\mathrm{d}}=0.5 \\
\varepsilon_{\mathrm{s}}=0.2\end{array}$ & $\begin{array}{c}\varepsilon_{\mathrm{d}}=0.5 \\
\varepsilon_{\mathrm{s}}=0\end{array}$ \\
\hline \multicolumn{4}{|c|}{ Target price $16.5 \mathrm{~d}$} \\
\hline $1928 / 29$ & $£ \mathrm{~m} 24.2$ & $£ \mathrm{~m} 16.9$ & $£ \mathrm{~m} 12.1$ \\
\hline $1929 / 30$ & $£ \mathrm{~m} 38.5$ & $£ \mathrm{~m} 26.9$ & $£ \mathrm{~m} 19.25$ \\
\hline \multicolumn{4}{|c|}{ Target price $18.94 \mathrm{~d}$} \\
\hline $1928 / 29$ & $£ \mathrm{~m} 40.4$ & $£ \mathrm{~m} 28.3$ & $£ \mathrm{~m} 20.2$ \\
\hline $1929 / 30$ & $£ \mathrm{~m} 58.4$ & $£ \mathrm{~m} 40.9$ & $£ \mathrm{~m} 29.2$ \\
\hline \multicolumn{4}{|c|}{ Target price $22.28 \mathrm{~d}$} \\
\hline $1928 / 29$ & $£ \mathrm{~m} 69.75$ & $£ \mathrm{~m} 48.8$ & $£ \mathrm{~m} 34.9$ \\
\hline $1929 / 30$ & $£ \mathrm{~m} 93.8$ & $£ \mathrm{~m} 65.6$ & $£ \mathrm{~m} 46.9$ \\
\hline
\end{tabular}

Source: figures are calculated by taking

Required purchases $=$ Australian production $\mathrm{x}[\%$ change in price aimed for (target price-actual price) $] / \varepsilon_{\mathrm{d} ; \mathrm{p}}$ lus Australian production $\mathrm{x}$ [\%change in price aimed for (target price-actual price) $] / \varepsilon_{\mathrm{s}}$

Sums required $=$ target price $\mathrm{x}$ Purchases required

Actual price and production numbers are taken from Australia, Commonwealth Bureau of Census and Statistics, Official Year Book.

This article is protected by copyright. All rights reserved. 
Table 7A. Hypothetical sums required to maintain the alternative average reserve prices of wool of Australian wool (assuming elasticities of $\varepsilon_{\mathrm{d}}=-0.5, \varepsilon_{\mathrm{s}}=0.5$ ) (Based on $\mathrm{NZ}$ and $\mathrm{SA}$ examples)

\begin{tabular}{|c|c|c|c|c|c|c|c|c|c|}
\hline \multicolumn{10}{|c|}{ RESERVE PRICE A (77 c/kg) } \\
\hline Year & $\begin{array}{l}\text { Actual } \\
\text { production } \\
\mathrm{m} \mathrm{kg}\end{array}$ & $\begin{array}{l}\text { Actual } \\
\text { price } \\
\text { c/kg }\end{array}$ & $\begin{array}{l}\text { Reserve } \\
\text { Price A } \\
\text { c/kg }\end{array}$ & $\begin{array}{c}\text { Required } \\
\text { Price increase } \\
\text { c/kg }\end{array}$ & $\begin{array}{c}\text { Required } \\
\text { price increase } \\
\%\end{array}$ & $\begin{array}{l}\text { Required } \\
\text { purchases } \\
\text { m kg }\end{array}$ & $\begin{array}{c}\text { Total } \\
\text { Demand } \\
\text { m kg }\end{array}$ & $\begin{array}{l}\text { Supply } \\
\text { m kg }\end{array}$ & $\begin{array}{c}\text { Funds } \\
\text { expended } \\
\$ \mathrm{~m}\end{array}$ \\
\hline $1958 / 59$ & 722 & 89 & 77 & 0 & 0 & 0 & 722 & 722 & 0 \\
\hline $1968 / 69$ & 884 & 82 & 77 & 0 & 0 & 0 & 884 & 884 & 0 \\
\hline $1969 / 70$ & 923 & 82 & 77 & 0 & 0 & 0 & 923 & 923 & 0 \\
\hline $1970 / 71$ & 886 & 65 & 77 & 12 & 18 & 164 & 968 & 804 & 106 \\
\hline $1971 / 72$ & 880 & 75 & 77 & 2 & 3 & 23 & 892 & 868 & 18 \\
\hline \multicolumn{10}{|c|}{ RESERVE PRICE B (82 c/kg) } \\
\hline Date & $\begin{array}{c}\text { Actual } \\
\text { production } \\
\mathrm{m} \mathrm{kg}\end{array}$ & $\begin{array}{l}\text { Actual } \\
\text { price } \\
\text { c/kg }\end{array}$ & $\begin{array}{c}\text { Reserve } \\
\text { Price B } \\
\text { c/kg }\end{array}$ & $\begin{array}{c}\text { Required } \\
\text { Price increase } \\
\text { c/kg }\end{array}$ & $\begin{array}{c}\text { Required } \\
\text { price increase } \\
\%\end{array}$ & $\begin{array}{l}\text { Required } \\
\text { purchases } \\
\text { m kg }\end{array}$ & $\begin{array}{c}\text { Total } \\
\text { Demand } \\
\text { m kg }\end{array}$ & $\begin{array}{l}\text { Supply } \\
\text { m kg }\end{array}$ & $\begin{array}{c}\text { Funds } \\
\text { expended } \\
\$ \mathrm{~m}\end{array}$ \\
\hline $1958 / 59$ & 722 & 89 & 82 & 0 & 0 & 0 & 722 & 722 & 0 \\
\hline $1968 / 69$ & 884 & 82 & 82 & 0 & 0 & 0 & 884 & 884 & 0 \\
\hline $1969 / 70$ & 923 & 82 & 82 & 0 & 0 & 0 & 923 & 923 & 0 \\
\hline 1970/71 & 886 & 65 & 82 & 17 & 26 & 232 & 1,002 & 770 & 151 \\
\hline $1971 / 72$ & 880 & 75 & 82 & 7 & 9 & 82 & 921 & 839 & 62 \\
\hline
\end{tabular}

This article is protected by copyright. All rights reserved. 
Table 7B. Hypothetical sums required to maintain the alternative average reserve prices of wool of Australian wool (assuming elasticities of $\varepsilon_{\mathrm{d}}=-0.5, \varepsilon_{\mathrm{s}}=0.5$ ) (Based on 1971 wool debate examples)

\begin{tabular}{|c|c|c|c|c|c|c|c|c|c|}
\hline \multicolumn{10}{|c|}{ RESERVE PRICE C (79 c/kg) } \\
\hline Year & $\begin{array}{c}\text { Actual } \\
\text { production } \\
\mathrm{m} \mathrm{kg}\end{array}$ & $\begin{array}{l}\text { Actual } \\
\text { price } \\
\text { c/kg }\end{array}$ & $\begin{array}{c}\text { Reserve } \\
\text { Price A } \\
\text { c/kg }\end{array}$ & $\begin{array}{c}\text { Required } \\
\text { Price increase } \\
\text { c/kg }\end{array}$ & $\begin{array}{c}\text { Required } \\
\text { price increase } \\
\%\end{array}$ & $\begin{array}{c}\text { Required } \\
\text { purchases } \\
\text { m kg }\end{array}$ & $\begin{array}{c}\text { Total } \\
\text { Demand } \\
\text { m kg }\end{array}$ & $\begin{array}{l}\text { Supply } \\
\text { m kg }\end{array}$ & $\begin{array}{c}\text { Funds } \\
\text { expended } \\
\$ \mathrm{~m}\end{array}$ \\
\hline $1958 / 59$ & 722 & 89 & 79 & 0 & 0 & 0 & 722 & 722 & 0 \\
\hline $1968 / 69$ & 884 & 82 & 79 & 0 & 0 & 0 & 884 & 884 & 0 \\
\hline $1969 / 70$ & 923 & 82 & 79 & 0 & 0 & 0 & 923 & 923 & 0 \\
\hline $1970 / 71$ & 886 & 65 & 79 & 14 & 22 & 191 & 981 & 791 & 124 \\
\hline $1971 / 72$ & 880 & 75 & 79 & 4 & 5 & 47 & 903 & 857 & 35 \\
\hline \multicolumn{10}{|c|}{ RESERVE PRICE D (88 c/kg) } \\
\hline Date & $\begin{array}{c}\text { Actual } \\
\text { production } \\
\mathrm{m} \mathrm{kg}\end{array}$ & $\begin{array}{l}\text { Actual } \\
\text { price } \\
\text { c/kg }\end{array}$ & $\begin{array}{c}\text { Reserve } \\
\text { Price C } \\
\text { c/kg }\end{array}$ & $\begin{array}{c}\text { Required } \\
\text { Price increase } \\
\text { c/kg }\end{array}$ & $\begin{array}{c}\text { Required } \\
\text { price increase } \\
\%\end{array}$ & $\begin{array}{c}\text { Required } \\
\text { purchases } \\
\text { m kg }\end{array}$ & $\begin{array}{c}\text { Total } \\
\text { Demand } \\
\text { m kg }\end{array}$ & $\begin{array}{l}\text { Supply } \\
\text { m kg }\end{array}$ & $\begin{array}{c}\text { Funds } \\
\text { expended } \\
\$ \mathrm{~m}\end{array}$ \\
\hline $1958 / 59$ & 722 & 89 & 88 & 0 & 0 & 0 & 722 & 722 & 0 \\
\hline $1968 / 69$ & 884 & 82 & 88 & 6 & 7 & 65 & 916 & 852 & 53 \\
\hline $1969 / 70$ & 923 & 82 & 88 & 6 & 7 & 68 & 957 & 889 & 55 \\
\hline $1970 / 71$ & 886 & 65 & 88 & 23 & 35 & 314 & 1,043 & 729 & 204 \\
\hline $1971 / 72$ & 880 & 75 & 89 & 13 & 17 & 153 & 956 & 804 & 114 \\
\hline
\end{tabular}

This article is protected by copyright. All rights reserved. 
Source: figures are calculated by taking

Required purchases $=$ Actual production $\mathrm{x}[\%$ change in price aimed for (target price-actual price) $] / \varepsilon_{\mathrm{d}}$ plus

Actual production $\mathrm{x}$ [\% change in price aimed for (target price-actual price)]/ $\varepsilon_{\mathrm{s}}$

Sums required $=$ target price $\mathrm{x}$ Required purchases

Actual price and production numbers are taken from Australia, Commonwealth Bureau of Census and Statistics, Official Year Book.

This article is protected by copyright. All rights reserved. 


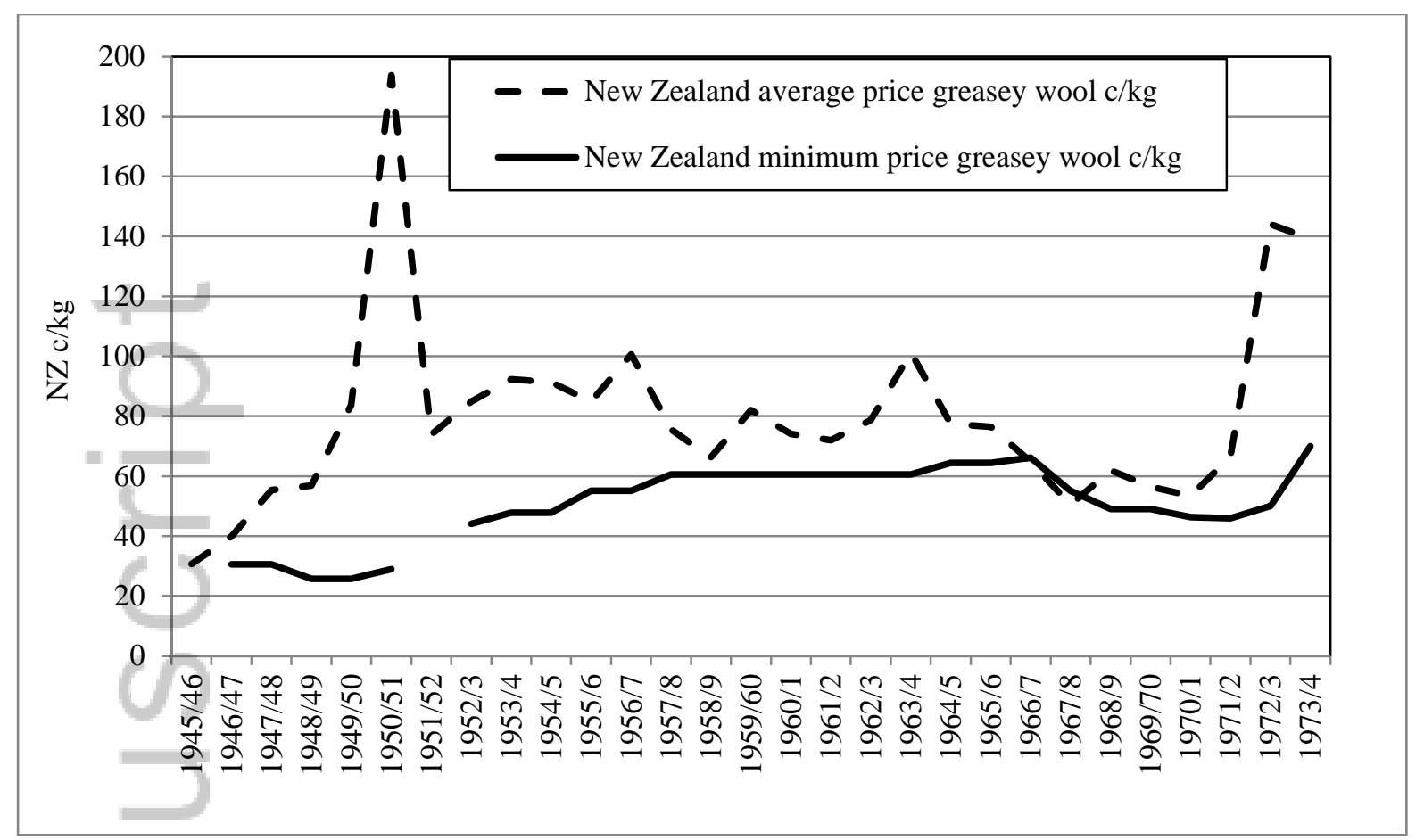

Figure 1. New Zealand average wool price in New Zealand currency (greasy) and reserve price, 1951/52 to $1973 / 74$, New Zealand cents/kg

Source: New Zealand Wool Commission, Reports and Statements of Account. (1952-74). McCarthy (1967)

This article is protected by copyright. All rights reserved. 


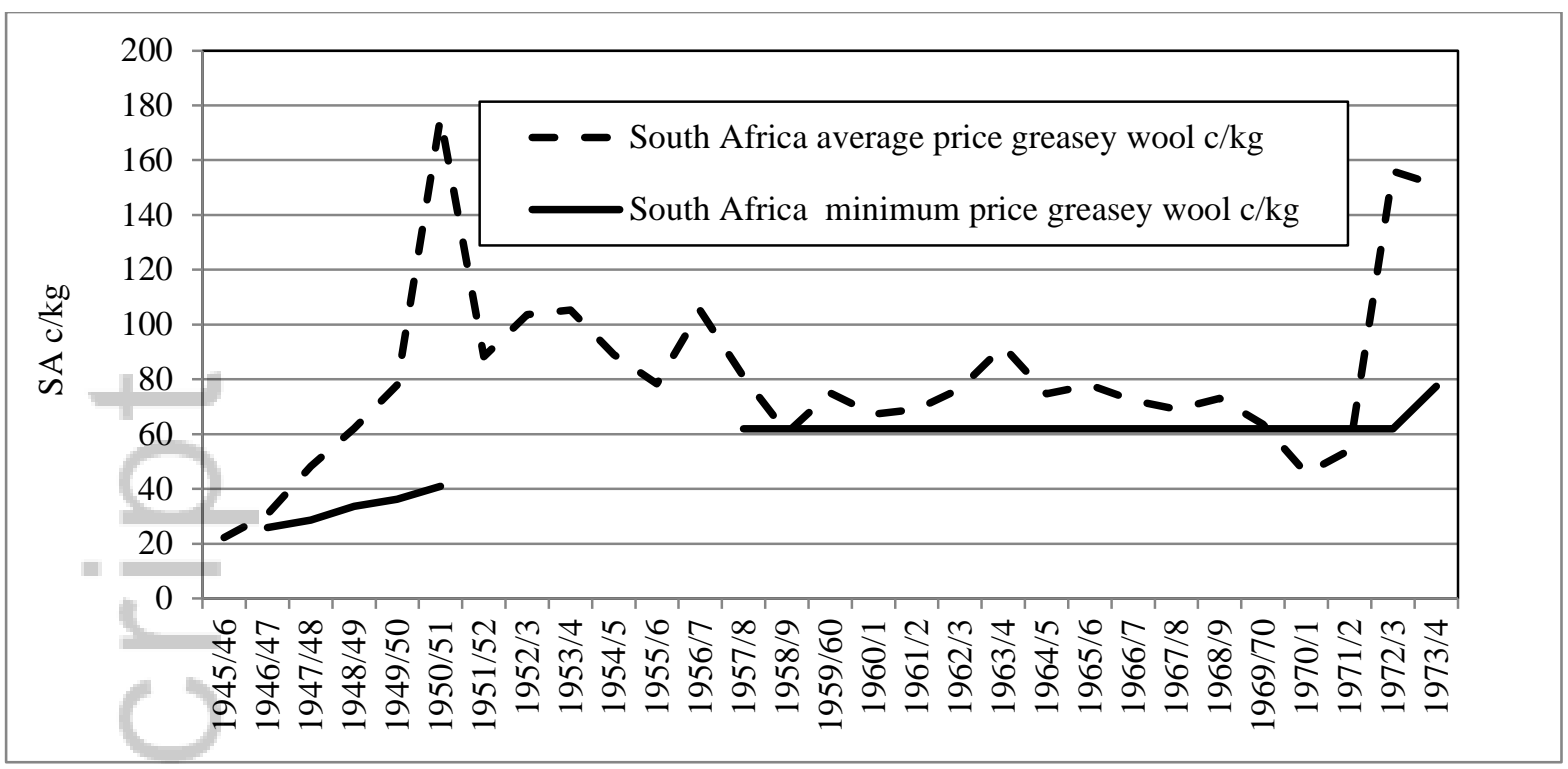

Figure 2. South African average wool price in South African currency (greasy) and reserve price 1951/52 to 1973/74, South African cents/kg.

Source: South Africa, Wool Commission, Annual Report (1960-74). McCarthy (1967).

This article is protected by copyright. All rights reserved. 


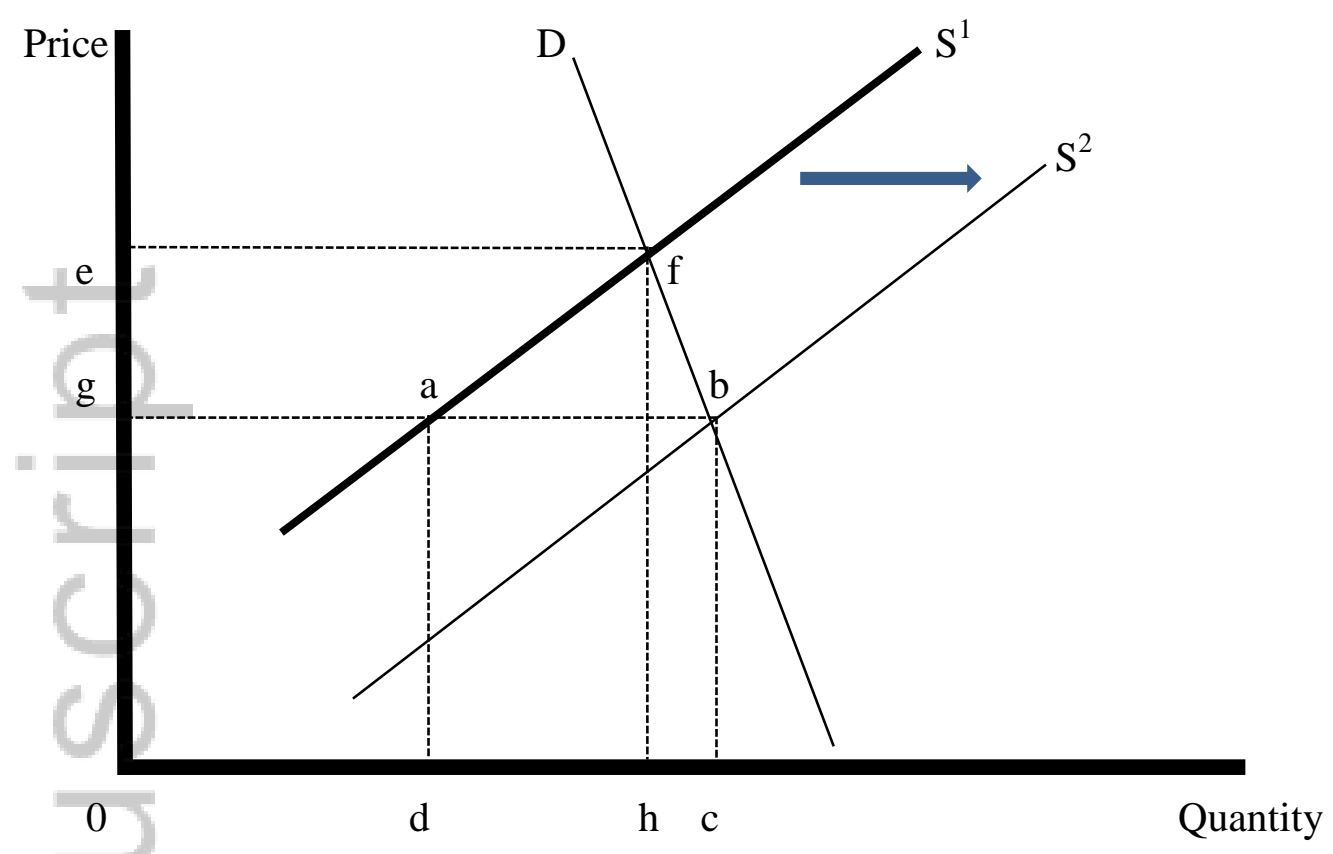

Figure 3: Demand and supply curves for the sale of wool from the BAWRA stockpile 1921

a to $\mathrm{b}$ - increase in sales from the stockpile (in 1921 approximately 800,000 bales)

$\mathrm{h}$ to $\mathrm{d}$ - reduction in new wool sales

c - new sales plus sales from the stockpile (actual 2,725,402 bales)

$\mathrm{e}$ - price if no sales from the stockpile (hypothetical $£ 27.51$ per bale)

$\mathrm{g}$ - price after sales from the stockpile (actual $£ 19.37$ per bale)

egfb - Producer Surplus (no stockpile sales)

efga-reduction in Producer Surplus caused by stockpile sales (LOSS) $(£ 17,300,722)$

abdc - revenue from stockpile sales (P x 800,000 bales) (GAIN) $(£ 15,495,000)$

This article is protected by copyright. All rights reserved. 


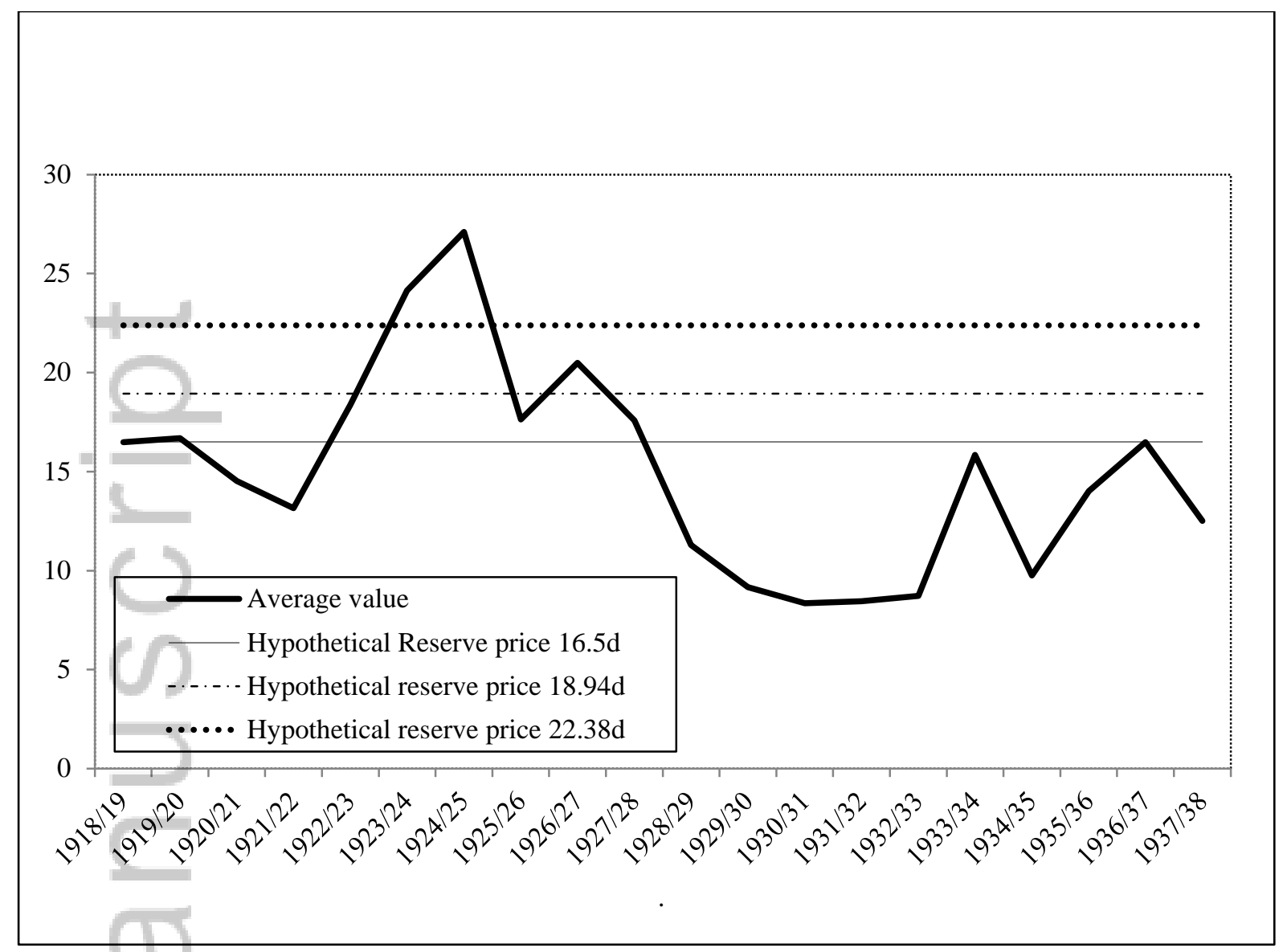

Figure 4. Average value of Australian greasy wool exports and alternative hypothetical reserve prices (d per Ib) $1918 / 19$ to $1937 / 38$.

Source: Australia, Commonwealth Bureau of Census and Statistics, Official Year Book (1919-38). Imperial Economic Committee (1928-30).

This article is protected by copyright. All rights reserved. 


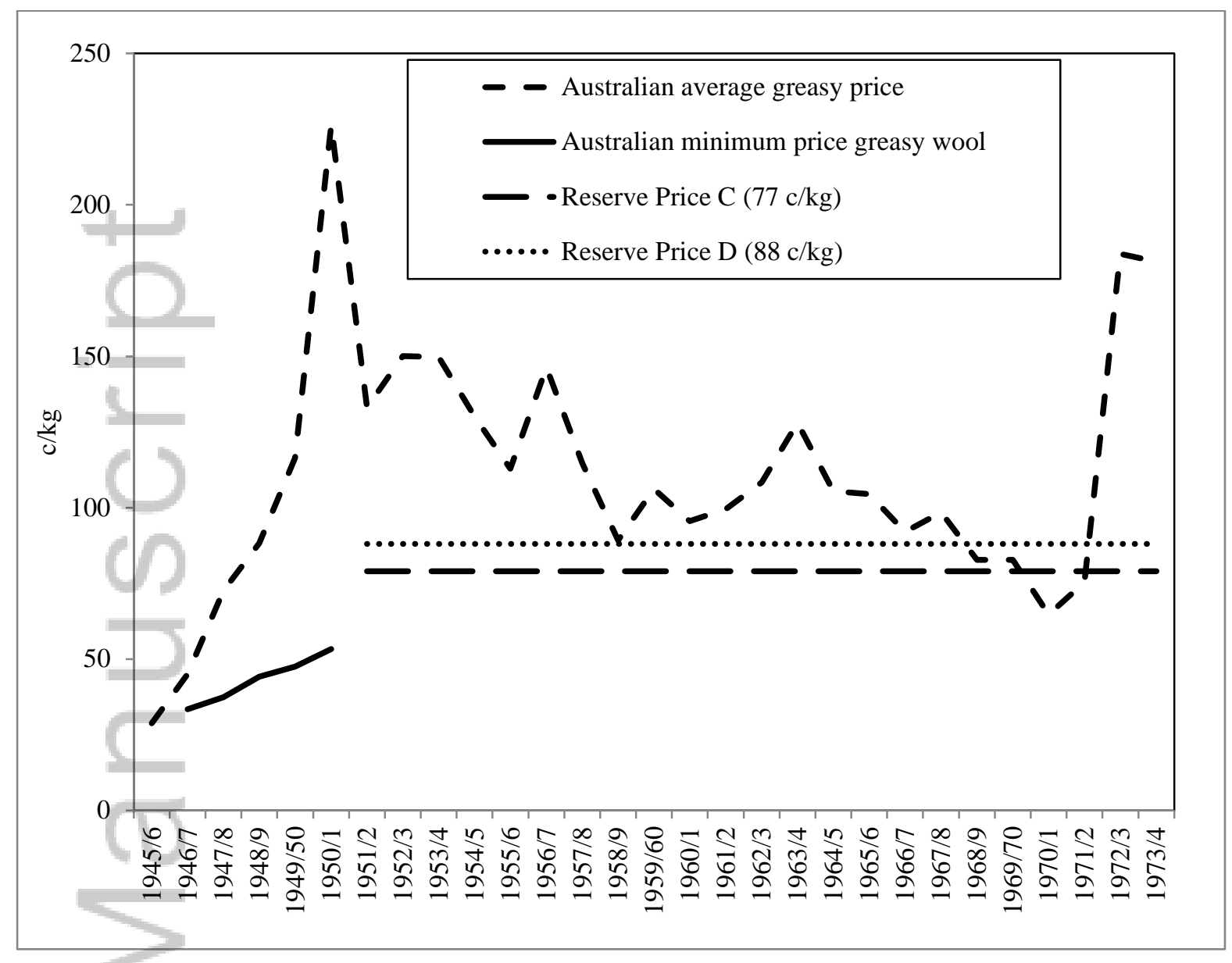
Figure 5. Average wool prices in Australian currency (greasy) 1945/46 to 1973/74,
Australian cents/kg.

Source: ABARE, Australian Commodities Statistics (1990). McCarthy (1967).

Notes: Australian prices tended to be higher than those of New Zealand and South Africa because throughout most of the period the Australian dollar was worth around 20 per cent less than the New Zealand dollar and South African Rand (the Australia currency remained at 20 per cent below that of the British pound up until the 1967 devaluation. The South African currency remained at parity with the British pound throughout and the New Zealand pound revaluated to parity in 1948). In addition, Australian prices tend to be higher than those of New Zealand because of the finer nature of Australian wool. 


\section{University Library}

\section{- M M I N E R VA A gateway to Melbourne's research publications}

Minerva Access is the Institutional Repository of The University of Melbourne

Author/s:

Abbott, M;Merrett, D

Title:

Was It Possible to Stabilise the Price of Wool? Organised Wool Marketing 1916 to 1970

Date:

2019-07

Citation:

Abbott, M. \& Merrett, D. (2019). Was It Possible to Stabilise the Price of Wool? Organised Wool Marketing 1916 to 1970. Australian Economic History Review: an Asia-Pacific journal of economic, business and social history, 59 (2), pp.202-227. https://doi.org/10.1111/ aehr.12136.

Persistent Link:

http://hdl.handle.net/11343/293262 